\title{
Adaptation of Synechococcus in situ determined by variability in intracellular phycoerythrin-543 at a coastal station off the Southern California coast, USA
}

\author{
M. Vernet, B. G. Mitchell, O. Holm-Hansen \\ Marine Research Division, A-002, Scripps Institution of Oceanography, University of California, San Diego, La Jolla, \\ California 92093, USA
}

\begin{abstract}
Concentrations of extracted phycobiliproteins were measured at a station off the Southern California coast, USA, from November 1985 to March 1986. The main pigment found was phycoerythrin-543 (PE) from Synechococcus spp. as described by Alberte et al. (1984). Concentrations of PE in water column, between 3 and $40 \mathrm{~m}$, varied between 0.01 and $1.60 \mu \mathrm{g} \mathrm{l} \mathrm{l}^{-1}$ Maximum values were found between 3 and $22 \mathrm{~m}$. In situ concentrations of $P E$ were positively correlated with cell numbers of Synechococcus spp., which ranged from 1.4 to $116 \times 10^{6}$ cells $l^{-1}$, and showed maximal values between 3 and $13 \mathrm{~m}$. Because no other types of PE were detected, all PE measured was considered to come from Synechococcus-type cells. Cellular concentrations of PE varied between 2.1 and $40.3 \times 10^{-9} \mu \mathrm{g} P E$ cell $^{-1}$, with an average value of $10.5 \pm 4.1 \times 10^{-9} \mu \mathrm{g} \mathrm{PE}$ cell-1 above the $1 \%$ isolume for PAR (Photosynthetically Available Radiation). Pigment per cell increased consistently with depth during autumn and spring and had low and relatively constant values in the winter. High PE:cell $\left(>20 \times 10^{-9}\right.$ $\mu \mathrm{g}$ PE cell ${ }^{-1}$ ) was observed only below the $1 \%$ isolume for PAR. For all samples, cellular concentration of PE was inversely correlated with incident PAR and was positively correlated to dissolved inorganic nitrogen (nitrate) concentration. Cyanobacteria were not a dominant component of phytoplankton standing stock during this study, contributing an estimated 4 to $15 \%$ of total chlorophyll in the water column, but had high specific growth rates, with maximal values of $>0.75 \mathrm{~d}^{-1}$ close to the surface. Absorption of light at $540 \mathrm{~nm}$, as measured by in vivo absorption spectra of phytoplankton, was not correlated with PE concentration in the water column.
\end{abstract}

\section{INTRODUCTION}

Phycobiliproteins are photosynthetic pigments present in 2 important phyla of marine phytoplankton: cynobacteria and cryptomonads. Whereas the latter group is well represented in estuarine and coastal waters (Gieskes \& Kraay 1983), cyanobacteria are now recognized as an important and ubiquitous component of marine phytoplankton, especially in open ocean waters (Waterbury et al. 1979, Glover 1985). The paucity of methods to estimate phycobiliproteins in the field has delayed the quantitative estimation of these pigments compared to chlorophylls and carotenoids. The techniques introduced by Stewart \& Farmer (1984) and Kilpatrick (1985) are a first step to quantitatively determine phycobiliproteins from phytoplankton, in particular the extraction of water-soluble pigments from cyanobacteria.
Intracellular phycobiliprotein concentration is dependant on environmental factors such as light and nutrients. Studies with laboratory cultures of cyanobacteria have shown that cellular concentrations of phycobiliproteins vary in response to irradiance (Barlow \& Alberte 1985, Wyman et al. 1985, Kana \& Glibert 1987 a), resulting in variable absorption cross section of the cell. Nutrient deficiency (especially nitrogen) is associated with a decrease in the phycoerythrin: chlorophyll a (PE:chl a) ratio (Yamanaka \& Glazer 1980) due in part to a recycling of the proteins associated with the phycobilisomes. In addition, several studies have stressed the role of phycobiliproteins, in particular phycoerythrin, as a nitrogen storage product in cyanobacteria (Kirchman \& Alberte 1985, Wyman et al. 1985, but see Kana \& Glibert 1987 a, b).

In this study we estimated PE concentration for aqueous extracts from samples collected at a station $1 \mathrm{~km}$ off 
the Southern California coast between October 1985 and March 1986. We present the vertical and temporal distribution of PE concentration and PE per cell in the water column and their response to several environmental factors.

\section{METHODS}

Water was collected 11 times from a station $1 \mathrm{~km}$ off Scripps Pier, California, USA $\left(32^{\circ} 50^{\prime} \mathrm{N}, 117^{\circ} 32^{\prime} \mathrm{W}\right)$ from October 1985 to March 1986. The site coincided with an underwater optical mooring placed $8 \mathrm{~m}$ below the sea surface (Booth et al. 1987). We used a small skiff equipped with a hydro-cable and power as a sampling platform. The skiff was launched using the facilities on the Scripps Institution of Oceanography Pier. Samples were taken from $3,8,13,22,28$ and $40 \mathrm{~m}$ with a $5 \mathrm{I}$ Niskin bottle, stored in dark 41 Nalgene polycarbonate bottles, and brought to the laboratory for further treatment. Continuous profiles from the surface to $60 \mathrm{~m}$ with a MER 1048 (Biospherical Instruments, Inc.) included photosynthetically available radiation (PAR), beam transmission (0.25 m transmissometer, Sea Tech, Inc.), temperature, and conductivity (Seabird Electronics, Inc.). Field data were stored in a battery-powered Kaypro portable computer and transferred to IBM PCcompatible computer for subsequent analysis

Pigment analysis. Chlorophyll a concentrations were estimated according to Holm-Hansen \& Riemann (1978). Two $50 \mathrm{ml}$ aliquots were filtered through $25 \mathrm{~mm}$ Whatman GF/F filters under a differential pressure of $12 \mathrm{~cm} \mathrm{Hg}$. Samples were extracted for $1 \mathrm{~h}$ in absolute methanol in the dark, subsequently shaken, centrifuged, and the fluorescence measured in a Turner Designs fluorometer (Model 10-005). Calibration of the fluorometer was done with chlorophyll a extracted from an exponentially growing culture of Isochrysis galbana

Phycobiliproteins were estimated following the method of Stewart \& Farmer (1984), with minor modifications. Between 1 and $4 \mathrm{l}$ of sample were filtered through a $47 \mathrm{~mm}$ Whatman GF/F filter under differential pressure of $12 \mathrm{~cm} \mathrm{Hg}$. Each filter was placed in $5 \mathrm{ml}$ of a solution consisting of $0.25 \mathrm{M}$ Trizma base (Sigma \#T1503), $10 \mathrm{mM}$ disodium EDTA, and $2 \mathrm{mg}$ $\mathrm{ml}^{-1}$ of lysozyme (Sigma) in deionized water. Samples were sonicated in an ice bath, the $\mathrm{pH}$ adjusted to 5.0

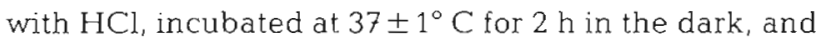
then for $20 \mathrm{~h}$ at $4^{\circ} \mathrm{C}$. The $\mathrm{pH}$ was then adjusted to 7.0 with $0.1 \mathrm{~N} \mathrm{NaOH}$ and the samples were cleared by filtration through an $8 \mu \mathrm{m}$ Nuclepore filter. Efficiency of extraction was tested on the material collected on the Nuclepore filter by measuring the ratio of absorption at $545 / 676$ and comparing to the ratio in whole cells. This test was performed in cells of Synechococcus clone WH7803.
Phycobiliproteins in the pigment mixture were identified by their fluorescence excitation and emission spectra characteristics by comparison with published spectra for cryptomonads and cyanobacteria (MacColl et al. 1976, Gantt 1979, Kursar \& Alberte 1983, Alberte et al. 1984, Stewart \& Farmer 1984, Haxo et al. 1987). Spectra were measured in a Perkin Elmer Fluorescence Spectrophotometer Model MFP-44A. Once per sampling date, samples were checked qualitatively for the presence of several phycobilins:excitation spectra were scanned in successive runs from $450 \mathrm{~nm}$ to the emission wavelength, with emission set at $560,565,575,580,600$ or $640 \mathrm{~nm}$ respectively. Spectra were measured in the ratio mode which corrects for relative quantum flux of the excitation beam by using rhodamine $B$ as a reference. Half-beam bandwidths of 10 and $3 \mathrm{~nm}$ were employed for the excitation and emission beam, respectively, for all work with the spectrofluorometer.

For quantitative studies, phycobiliprotein-543 concentration was estimated by the intensity of the fluorescence emission signal at $562 \mathrm{~nm}$ with excitation set at $520 \mathrm{~nm}$. Samples were always scanned for fluorescence emission from 540 to $600 \mathrm{~nm}$ to verify the purity of the peak. A calibration curve was established between concentration of PE-543 and intensity of fluorescence emission from a dilution series of known concentration of PE extracted from Synechococcus clone WH7803: absorption maximum at $542 \mathrm{~nm}$, weight-specific absorption coefficient of $8.2 \mathrm{lg}^{-1} \mathrm{~cm}^{-1}$ (Alberte et al. 1984).

Nutrients. Water samples for analysis of $\mathrm{NO}_{3}{ }^{-}$were stored frozen in $125 \mathrm{ml}$ plastic bottles after filtration through Whatman GF/F filters. Analyses were performed at the University of Southern California Analysis Lab in an Amicon 5-channel autoanalyzer following standard colorimetric methods (Strickland \& Parsons 1972).

Cell counts. Cyanobacteria abundance was estimated by enumeration of autofluorescent cells. Cells were concentrated onto $25 \mathrm{~mm}$ Nuclepore polycarbonate filters $(0.4 \mu \mathrm{m}$ pore diameter) previously stained with Irgalan Black solution. Replicate samples $(50$ to $100 \mathrm{ml}$ ) were taken from each depth and filtered under a differential pressure of $5 \mathrm{~cm} \mathrm{Hg}$. A drop of glycerol was placed between filter and cover slip. Samples were kept at $-20^{\circ} \mathrm{C}$ in the dark and counted within a week on an Olympus microscope Model $\mathrm{BH}-2$ with excitation and emission filters as specified for acridine orange in Hobbie et al. (1977).

Primary production and photosynthetic partitioning. On 19 February 1986 an experiment to partition the in situ production was conducted to determine the contribution by cyanobacteria to total production, and to estimate their growth rates. Total primary production was estimated using ${ }^{14} \mathrm{C}$-bicarbonate as a tracer of 
inorganic carbon incorporation (Steemann Nielsen 1952). Duplicate $125 \mathrm{ml}$ light bottles and one dark bottle were suspended in situ at the sampling depth for $6 \mathrm{~h}$ starting at 10:00 h. Care was taken to minimize exposure to surface light and hence light shock. Samples were filtered onto Whatman GF/F filters, fumed with vapor from concentrated $\mathrm{HCl}$ and activity determined in a liquid scintillation counter.

Cyanobacteria production was determined by estimating the mean cellular production. Replicate 100 ml light samples and one dark sample were filtered through Whatman 934AH filters and the filtrate was subsequently filtered onto Nuclepore $0.4 \mu \mathrm{m}$ polycarbonate filters. Iturriaga \& Mitchell (1986) have demonstrated that greater than $50 \%$ of the Synechococcus pass through the $934 \mathrm{AH}$ filter type. The 3 (2 light and 1 dark preparation) $0.4 \mu \mathrm{m}$ Nuclepore filters containing radio-labeled Synechococcus were then mounted on microscope slides in the standard procedure for cell count preparations and the slides were stored dark at $4^{\circ} \mathrm{C}$ until counted. Synechococcus (yellow fluorescing) and red fluorescent particles were counted within $4 \mathrm{~h}$ after preparation. After counting, the filter and cover slip were placed in a scintillation vial. A small piece of laboratory tissue with a drop of methanol was used to remove any residual glycerol from the microscope slide, and this was added to the scintillation vial. The samples in the vial were then fumed in acid and radioactivity determined as above.

Fewer than $5 \%$ of the particles counted were red fluorescing, so we make the assumption that all of the radioactivity in these preparations is due to Synechococcus which passed the 934AH filter This procedure allows a direct estimate of production per Synechococcus cell. Total cyanobacteria production was determined by dividing the production determined for the Synechococcus passing the $934 \mathrm{AH}$ and retained on the $0.4 \mu \mathrm{m}$ filter by the fraction of Synechococcus counted for the filtrate as compared to total counts of Synechococcus. This procedure is more direct than the determinations by difference described by Iturriaga \& Mitchell (1986) and is therefore considered more accurate. This is important for coastal waters since a smaller fraction of total production is attributable to Synechococcus compared to the open ocean stations they described.

Growth rates of Synechococcus were determined by the general natural $\log$ exponential equation $\mu=\ln [$ ( $\mathrm{C}$ cell ${ }^{-1}+\Delta \mathrm{C}$ cell $\left.^{-1}\right) / C$ cell $\left.{ }^{-1}\right] / t$, where $C$ is carbon, $\Delta C$ is the carbon increase over period $t$, and thas units of $d^{-1}$. Cellular carbon was estimated by using an average cell size of $l \mu \mathrm{m}$ diameter, determined microscopically, and assuming $0.2 \mathrm{pg} \mathrm{C} \mu \mathrm{m}^{3}$ of cell volume as determined by Kana \& Glibert (1987b). The observed cell diameter coincides with previous determinations of Krempin \&
Sullivan (1981) and Iturriaga \& Mitchell (1986) for natural populations of Synechococcus spp.

Particulate optical properties. Samples collected from the water column (500 to $1000 \mathrm{ml}$ ) were filtered onto Whatman GF/F filters for determination of spectral absorption coefficients (Mitchell \& Kiefer 1988). Determinations of particulate absorption (350 to $750 \mathrm{~nm}$ ) were accomplished using a Beckman Acta IV spectrophotometer. All spectra were transferred to an IBM PC compatible computer and stored on disk for later analysis.

\section{RESULTS}

Our sampling interval was designed to resolve phenomena occurring on scales of weeks to months. We observed autumn-winter and winter-spring transitions. Fig. 1 depicts water column characteristics encountered during the sampling period: (a) stratified $(5$ to $10 \mathrm{~m}$ ) mixed layers with relatively low phytoplankton biomass (ca $1 \mu \mathrm{g} \mathrm{chl} \mathrm{a} \mathrm{I}^{-1}$ ) in late autumn (20 November 1985), (b) deeper mixed layers $(>20 \mathrm{~m}$ ) and low phytoplankton standing stock throughout $(<1 \mu \mathrm{g}$ chl a $\left.\mathrm{l}^{-1}\right)$, characteristic during most of the winter $(8$ January 1986), and (c) shallow mixed layers or continuously stratified with higher biomass in the mixed layer (>2 $\mu \mathrm{g} \mathrm{chl} \mathrm{a} \mathrm{l}^{-1}$ ) and/or well-developed particle maximum (20 March 1986) typical of springtime. Mixed layer depth varied from less than 5 to greater than $25 \mathrm{~m}$ and the $1 \%$ isolume for PAR varied from 18 to $50 \mathrm{~m}$. During periods of most intense mixing during winter storms, it was not possible to launch the skiff from the pier, so it is likely that deeper, episodic mixing occurred during winter.

The extracted phycobiliproteins from field samples showed 2 major peaks in fluorescence excitation spectra at 495 and $543 \mathrm{~nm}$ (Fig. 2), for $562 \mathrm{~nm}$ emission. Fluorescence emission showed a major peak at 560 to $562 \mathrm{~nm}$ when the sample was excited at $470,495,520$ or $543 \mathrm{~nm}$. These fluorescence excitation and emission peaks were at the same wavelength $( \pm 3 \mathrm{~nm}$ ) as those observed for extracted phycobiliproteins of Synechococcus clones WH7803 (DC-2) (Fig. 2) and WH6581 (SYN 48).

Phycoerythrin-543 concentration varied between 0.01 and $1.6 \mu \mathrm{g} \mathrm{l}^{-1}$, and was maximal between 8 and $20 \mathrm{~m}$ (Fig. 3a). Low concentrations were observed below $30 \mathrm{~m}$. Highest pigment concentrations coincided with periods of stronger stratification in late autumn and early spring. Cell numbers of Synechococcus ranged from 1.4 to $116 \times 10^{6}$ cells $^{-1}$ (Fig. 3b). Maximal cell concentrations were found near the surface $(3$ to $13 \mathrm{~m}$ ) during late autumn and early spring and during periods of water column stratification in winter. A strong vertical stratification in cell concentration from 

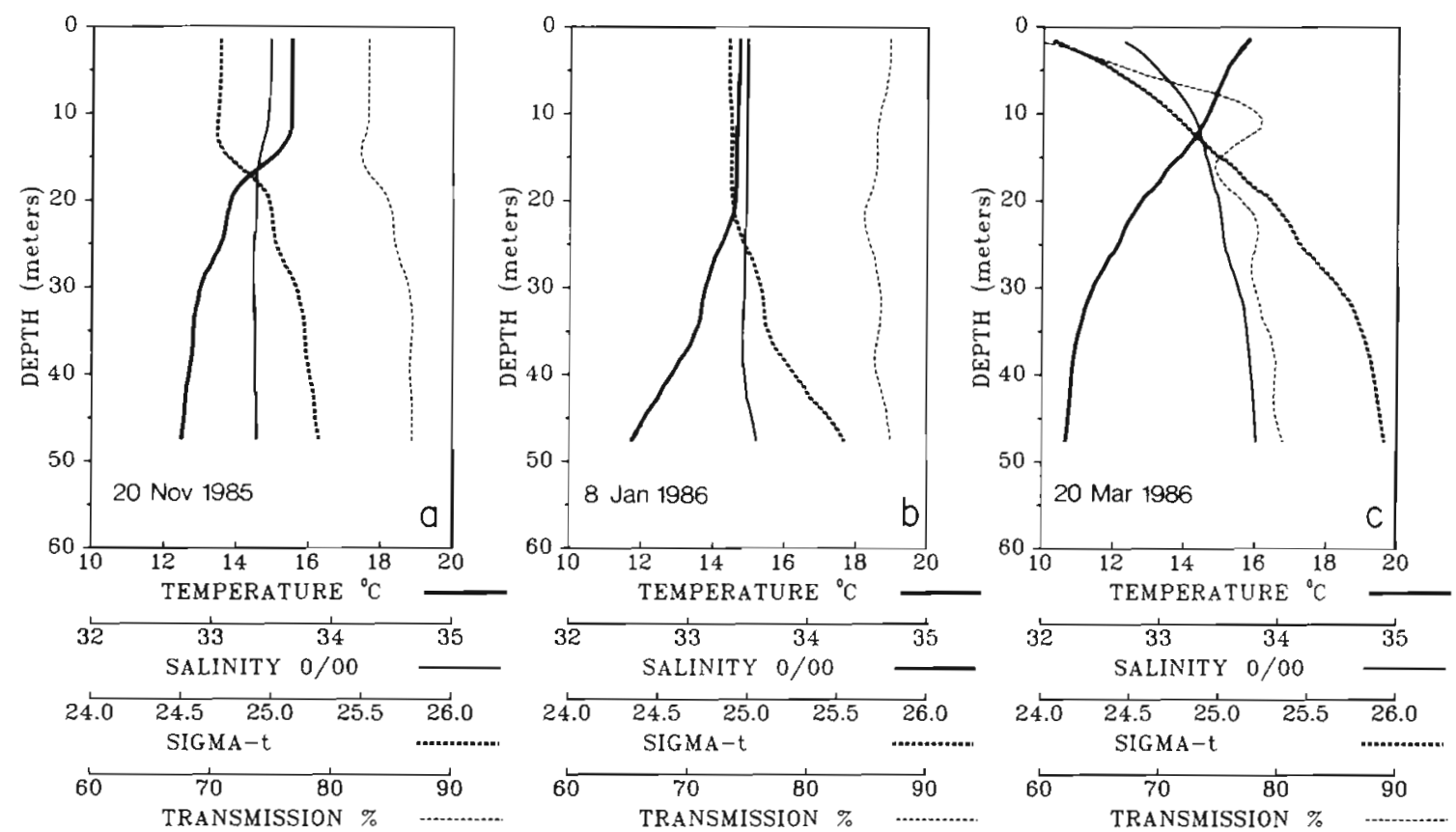

Fig. 1. Vertical structure of salinity, temperature, density, and beam transmission of the water column at the station $1 \mathrm{~km}$ off Scripps Pier. Dates shown exemplify the conditions during different seasons: (a) autumn 1985, (b) winter 1986, (c) spring 1986

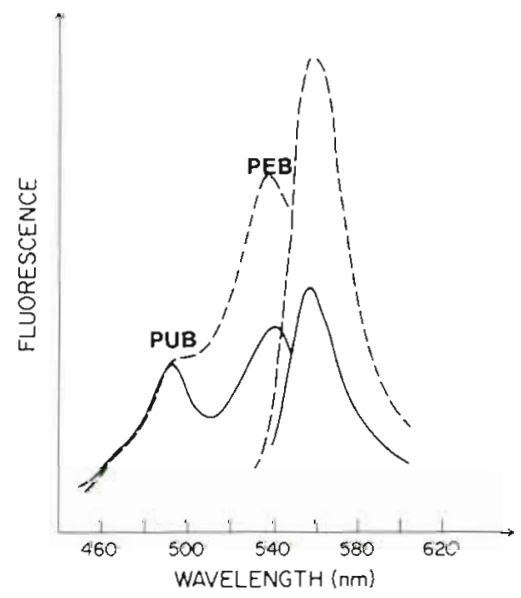

Fig. 2. Extracted phycoerythrin from field populations (-and from Synechococcus clone WH7803 (---) excitation (460 to $540 \mathrm{~nm}$ ) and emission (530 to $600 \mathrm{~nm}$ ) spectra in Trizma base and sodium EDTA buffer, $\mathrm{pH} 7$. For emission spectra the excitation wavelength was $520 \mathrm{~nm}$ and for excitation spectra the emission wavelength was $562 \mathrm{~nm}$. Fluorescence in arbitrary units. Excitation peaks at 495 and $543 \mathrm{~nm}$ correspond to absorption by phycourobilin (PUB) and phycoerythrobilin $(\mathrm{PEB})$ respectively

3 to $40 \mathrm{~m}$ was observed in autumn and spring (20- to 30 -fold decrease with depth). Cell concentrations in winter were lower and there was less vertical stratification (2- to 10-fold decrease).

Since no other types of phycoerythrin were detected by fluorescence emission in the extracts (Fig. 2), all phycoerythrin measured was considered to come from Synechococcus-type cells (phycoerythrin-543). An estimate of phycoerythrin-543 concentration per cell shows an increase with depth although the amount of pigment per cell showed considerable variability between days for any given depth (Fig. 3c). For example, PE:cell at $3 \mathrm{~m}$ varied between 2.1 and $10.7 \times 10^{-9}$ $\mu \mathrm{PE}$ cell ${ }^{-1}$. Winter values, from mid-December to mid-February, are characteristically low throughout the upper $40 \mathrm{~m}$ (2.3 to $16.9 \times 10^{-9} \mu \mathrm{g} \mathrm{PE}$ cell $\left.{ }^{-1}\right)$. Late autumn and early spring show profiles with higher values in the water column: surface values are generally higher than in winter $\left(6.4\right.$ to $16.4 \times 10^{-9} \mu \mathrm{g} \mathrm{PE}$ cell $^{-1}$ ) and deep samples (23 to $40 \mathrm{~m}$ ) show the highest values observed during this study (15.6 to $40.3 \times 10^{-9}$ ug PE cell ${ }^{-1}$ ).

Synechococcus abundance, on average, can be predicted from $\mathrm{PE}$ concentration using a linear estimator (Fig. 4). From the slope it is estimated that the average PE:cell for the period studied was $10.5 \pm 4.1 \times 10^{-9} \mu \mathrm{g}$ PE cell ${ }^{-1}$

The change of PE:cell in the field was assessed relative to environmental factors known to affect its concentration under controlled conditions (Wyman et al. 1985, Kana \& Glibert 1987a). The concentration of $P E$ :cell in the samples was inversely correlated to the $\log$ of the ratio of PAR at depth to the incident PAR (Fig. 5; Table 1) and to temperature but was positively correlated to total dissolved inorganic nitrogen (Table 1). The environmental variables were strongly corre- 

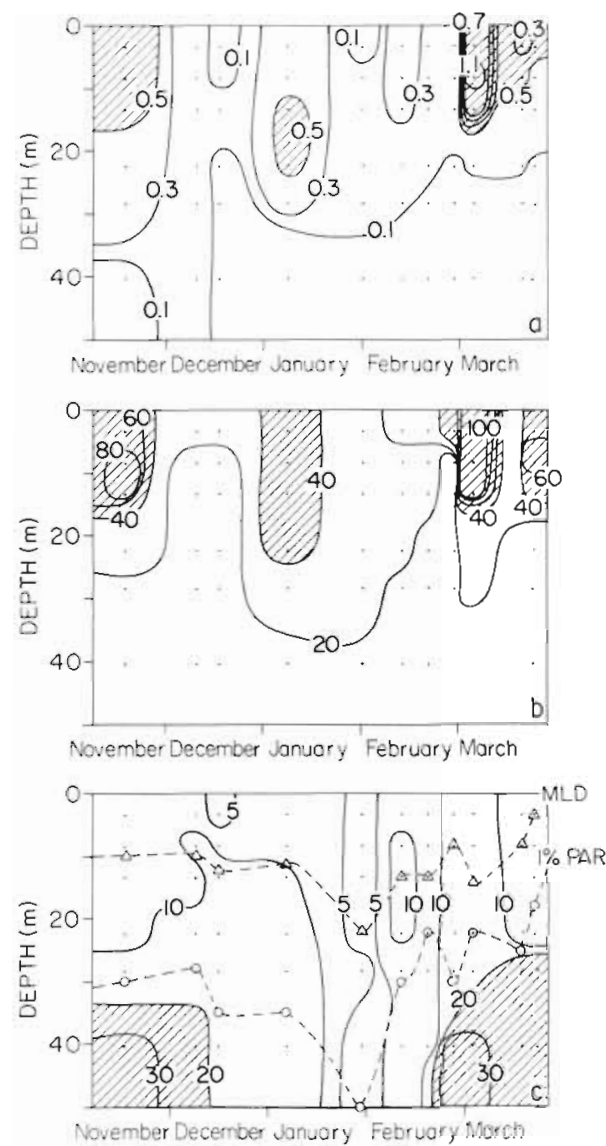

Fig. 3. Contours of field concentrations of Synechococcus-type cells and their phycobiliproteins: (a) concentration of extracted phycoerythrin-543 (PE-543, $\left.\mu \mathrm{g} \mathrm{l}^{-1}\right)$; (b) distribution of Synechococcus cell concentration $\left(\times 10^{6}\right.$ cells $\left.1^{-1}\right) ;$ (c) estimated PE-543:cell for Synechococcus spp. $\left(\times 10^{-9} \mu \mathrm{g} \mathrm{PE}\right.$ cell $\left.{ }^{-1}\right)$. ( $\Delta$ ) Depth of the mixed layer (MLD); (o) $1 \%$ isolume for PAR

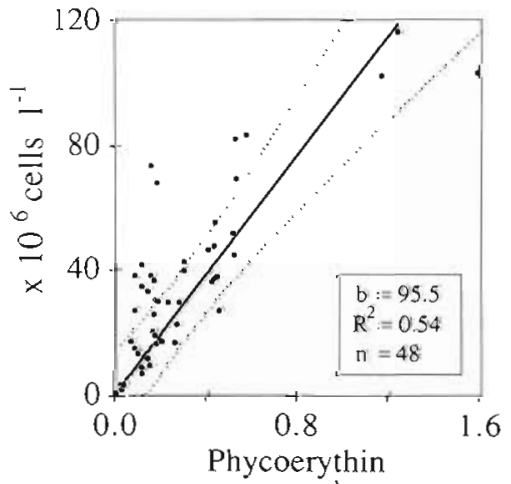

$\left(\mu \mathrm{g} \mathrm{1^{-1 }}\right)$

Fig. 4. Synechococcus abundance in the euphotic zone (above $1 \%$ PAR) as a function of phycoerythin- 543 concentraion $(\mu \mathrm{g}$ $1^{-1}$ ) and assuming zero intercept: $\mathrm{r}^{2}=0.54, \mathrm{n}=48 ; \mathrm{Ho}: \mathrm{b} \neq 0, \mathrm{t}$ $=15.48, \mathrm{df}=46, \mathrm{p}<0.001$ (Student's t-test). Dotted lines represent $95 \%$ conficence interval of the estimate of $\mathrm{Y}=$ cell concentration. Average intracellular pigment concentration calculated from the slope of the line is $10.5 \pm 4.1 \times 10^{-9} \mathrm{\mu g} P E$ cell $^{-1}$

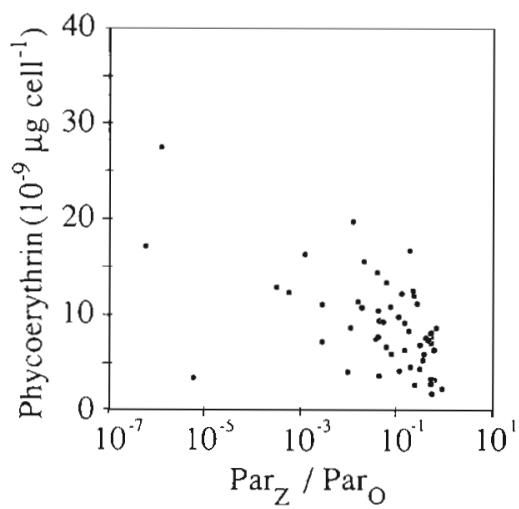

Fig. 5. PE:cell as a function of $\log$ of the ratio of in situ to incident photosynthetically available radiation (PAR): $r=$ $-0.583, \mathrm{n}=60, \mathrm{p}<0.001$ (Spearman Rank correlation test)

Table 1. Spearman Rank correlations of PE:cell with environmental variables including the ratio of in situ to incident PAR (PAR(z)/PAR(o)), dissolved nitrate and temperature. (Irradiance data were not available for one of the sampling dates)

\begin{tabular}{|lrrl|}
\hline Variable & $r$ & $n$ & Significance \\
\hline PE:cell vs log(PAR(z)/PAR(o)) & -0.583 & 60 & $\mathrm{p}<0.001$ \\
PE:cell vs Temperature & -0.559 & 66 & $\mathrm{p}<0.001$ \\
PE:cell vs Nitrate & 0.488 & 66 & $\mathrm{p}<0.001$ \\
PAR(z)/PAR(o) vs Temperature & 0.733 & 60 & $\mathrm{p}<0.001$ \\
PAR(z)/PAR(o) vs Nitrate & -0.784 & 60 & $\mathrm{p}<0.001$ \\
Temperature vs Nitrate & -0.868 & 66 & $\mathrm{p}<0.001$ \\
& & & \\
\hline
\end{tabular}

lated among themselves, in particular nitrate concentration and temperature. All correlations were significant at $\mathrm{p}<0.001$ using the non-parametric Spearman Rank test (Zar 1984).

The contribution of Synechococcus cells to algal biomass was estimated as a percentage of total chlorophyll a due to cyanobacteria. Chlorophyll a concentrations attributed to Synechococcus were estimated using measured PE:cell and assuming a variable PE:chl a ratio, as seen by Kana \& Glibert $(1987 \mathrm{a}, \mathrm{b})$. In this manner, chlorophyll a from Synechococcus was estimated to contribute between 2 and $15 \%$ of the total chlorophyll biomass with an average of $4 \%$ and maximal values from 3 to $13 \mathrm{~m}$. Cellular growth rates in winter were highly stratified (Table 2) with maximal values $\left(u>0.75 \mathrm{~d}^{-1}\right)$ close to the surface $(3 \mathrm{~m})$ and measurable growth down to $22 \mathrm{~m}(0.3 \%$ PAR; see Table 2). The mean cyanobacteria production was $20 \%$ of the total ${ }^{14} \mathrm{C}$ incorporation for the experiment.

Absorption of light by PE from Synechococcus was not prominent in the total particulate specific absorption spectra. Although a minor peak of absorption was distinguishable from 540 to $550 \mathrm{~nm}$ in (chl+phaeopigment)-specific spectral absorption coefficient no corre- 
Table 2. Synechococcus growth rates and photosynthetic partitioning on 19 February 1986 . The data exemplify the stratification of the water column with depth showing a characteristic decrease in cell number (Cyano. cell conc.), an increase in nitrate concentration (Nitrate), irradiance estimated as the percent irradiance at depth $z$ relative to irradiance just below the water surface $\{(\operatorname{PAR}(z) / \mathrm{PAR}(0)) \times 100]$, and concomitant decreases in primary production of the whole phytoplankton assemblage (Total production), production of the $<1 \mu \mathrm{m}$ fraction (Cyano. production), and the estimated carbon-specific growth rate of Synechococcus (Cyano. $\mu$ )

\begin{tabular}{|ccccccc|}
\hline $\begin{array}{c}\text { Depth } \\
(\mathrm{m})\end{array}$ & $\begin{array}{c}\text { Cyano, cell conc. } \\
\left.\text { (cells ml } \mathrm{ml}^{-1}\right)\end{array}$ & $\begin{array}{c}\text { Nitrate } \\
(\mu \mathrm{M})\end{array}$ & \% PAR & $\begin{array}{c}\text { Total production } \\
\left(\mathrm{mgC} \mathrm{m}^{-3} \mathrm{~d}^{-1}\right)\end{array}$ & $\begin{array}{c}\text { Cyano. production } \\
\left(\mathrm{mgC} \mathrm{m}^{-3} \mathrm{~d}^{-1}\right)\end{array}$ & $\begin{array}{c}\text { Cyano. } \\
\mu\left(\mathrm{d}^{-1}\right)\end{array}$ \\
\hline 3 & 28390 & 0.34 & 50 & 22.0 & 3.3 & 0.75 \\
8 & 33070 & 0.39 & 19 & 8.1 & 0.4 & 0.42 \\
13 & 22670 & 1.30 & 7.8 & 3.1 & 0.2 & 0.17 \\
22 & 18020 & 4.10 & 0.3 & 0 & 0 & 0 \\
28 & 7970 & 2.70 & $<0.1$ & 0 & 0 & 0 \\
40 & 7420 & 5.8 & $<0.1$ & 0 & 0 & 0 \\
\hline
\end{tabular}

lation was observed for all samples between peak height or peak area at $545 \mathrm{~nm}$ in the absorption spectra and PE concentration.

\section{DISCUSSION}

The 495 and $543 \mathrm{~nm}$ fluorescence excitation peaks of field samples correspond to the 2 chromophores present in phycoerythrin of Synechococcus strains WH 7803 and WH 6581 as described in Ong et al. (1984) and in Alberte et al. (1984), phycourobilin (PUB) and phycoerythrobilin (PEB), respectively (Fig. 2). Field samples showed a higher proportion of the PUB chromophore with respect to the PEB chromophore when compared to Synechococcus clone WH7803. The fluorescence excitation ratio between $495: 543 \mathrm{~nm}$ of 0.75 suggests that the clones present in waters off Southern California are more similar to clone-type WH8108 (Waterbury et al. 1986) and populations from open ocean environments (Campbell \& Iturriaga 1988).

Synechococcus abundance during autumn 1985 to spring 1986 was comparable in numbers to other areas in Southern California (Krempin \& Sullivan 1981: San Pedro Channel; Putt \& Prézelin 1985: Santa Barbara Channel) and to other coastal regions (El Hag \& Fogg 1986, Waterbury et al. 1986, Carpenter \& Campbell 1988). Low cell numbers were always found at depth. Maximal concentration $\left(116 \times 10^{6}\right.$ cells $1^{-1} ; 3 \mathrm{~m}, 3$ March 1986 during a netplankton bloom) was very similar to cell concentration in Santa Barbara Channel (Putt \& Prézelin 1985). The significant relationship between cell number and pigment concentration suggests that, in the field, Synechococcus abundance might be estimated from PE concentrations, for example, from airborne sensors (Hoge \& Swift 1986), using a conversion factor of $10.5 \pm 4.1 \times 10^{-9} \mu \mathrm{g} \mathrm{PE} \mathrm{cell}{ }^{-1}$ (Fig 4) for this area. Although cellular concentrations of PE vary, apparently due to photoddaptation, PE:cell varies less (20-fold) than does the total PE concentration, or cell numbers (ca 100-fold each). Furthermore, PE:cell varied only 5 -fold in the surface layer bounded by the depth where $570 \mathrm{~nm}$ light is reduced to 1/e of its surface value (Mitchell unpubl.). This is the layer which is relevant for remote sensing (Gordon \& McCluney 1975). If fluorescence yields of PE are relatively constant, remotely sensed fluorescence of phycoerythrin (e.g. Hoge \& Swift 1986) should be able to estimate Synechococcus cell numbers with similar precision as estimates of chlorophyll-like pigments using standard passive remote sensing algorithms (Gordon et al. 1983).

The range of values of $P E$ :cell observed in the water column (2.2 to $40.3 \times 10^{-9} \mu \mathrm{g}$ PE cell ${ }^{-1}$ ) overlap the range in values measured by Barlow \& Alberte (1985) in clone WH7803 (DC-2) (27 to $50 \times 10^{-9} \mu \mathrm{g} \mathrm{PE} \mathrm{cell}{ }^{-1}$ for cells grown from 10 to $250 \mu \mathrm{E} \mathrm{m}^{-2} \mathrm{~s}^{-1}$ ). Low PE: cell values observed mostly in the upper $20 \mathrm{~m}$ are similar to values presented by Kana \& Glibert (1987a) for clone WH7803 grown from 400 to $2000 \mu \mathrm{E} \mathrm{m}^{-2} \mathrm{~s}^{-1}$ (4.7 to $18 \times$ $10^{-9} \mu \mathrm{g}$ PE cell ${ }^{-1}$ ). Our lowest values of PE:cell for field samples (to $2.2 \times 10^{-9} \mu \mathrm{g}$ PE cell ${ }^{-1}$ ) might be due to smaller cell size in field populations (ca $0.8 \times 1.2 \mu \mathrm{m}$ ) compared to cultures (ca $1.2 \times 1.6 \mu \mathrm{m}$; Kana \& Glibert 1987 a).

Although we estimated growth rates for only 1 date, the observed high growth rates (Table 2) and the low PE:cell in the mixed layer, similar to that found by Kana \& Glibert (1987a) for clone WH7803 at high irradiances, support the hypothesis that Synechococcus can have high growth rates in surface waters with relatively high ambient light intensity as long as the cells have had time to adapt to the new light regime (see also Landry et al. 1984, Iturriaga \& Mitchell 1986).

It was hypothesized that in variable environments, like Southern California waters influenced by periods of upwelling, cells would have low PE:cell values in surface waters during periods of water stratification where cells were expected to have decreased mixing 
and thus enough time to adapt to high-light conditions During periods of deep mixing, cells were expected to be mixed deeper in the euphotic zone and, on average, adapted to lower light conditions, and thus PE:cell will be, on average, higher Deep mixing is most probable in winter coinciding with minimal total solar radiation and daylength. This scenario was not observed in the field (Fig. 3c): while in autumn and spring PE:cell in the surface was low and increased 3 to 5 times with depth, winter values were consistently low from the surface to $40 \mathrm{~m}$.

Low values of PE:cell observed in well-mixed waters in winter can be interpreted as cells adapted to high irradiances throughout the photic zone. When comparing PE:cell with mixed layer depth (MLD) and the depth of $1 \%$ PAR (Fig. 3c) it is evident that the low PE:cell values in winter are associated with clear and well-illuminated waters. It is only below the $1 \%$ isolume for PAR that the Synechococcus cells adapt to high (>20 $\times 10^{-9} \mu \mathrm{g} \mathrm{PE}$ cell $\left.{ }^{-1}\right)$ values of PE:cell. Species such as cyanobacteria previously considered to be characteristic of low-light environments (Glover 1985) and which need long periods of time to acclimate to high irradiances (Kana \& Glibert 1987a) may need to maintain characteristics of adaptation to high light in pre-bloom situations. Thus they may have a strategy whereby they are adapted to the highest irradiance to which they are exposed rather than the mean irradiance. This would enable cells to survive and grow fast once stratification is achieved and would allow them to have uninhibited growth when mixed to the surface during weakly stratified conditions.

In addition to total incident radiation other environmental factors such as nutrient availability and temperature may influence the ratio of PE:cell. Cells grown at high nutrient concentrations have been shown to have high PE:cell (Kirchman \& Alberte 1985, Wyman et al. 1985, Glibert et al. 1986). Surface and deep values of temperature and nutrients were similar throughout the sampling period (unpubl.). Observed growth rates for Synechococcus were highest near the surface (Table 2) implying that surface nutrients were adequate to support high growth rates in midwinter. All the physical variables are correlated with depth so it is difficult to specify the causal parameter for depth changes in PE:cell. Since values exceeding $20 \mu \mathrm{gPE}$ cell $^{-1}$ were only observed below the $1 \%$ isolume for PAR, and low values of PE:cell were observed at all depths during higher clarity winter conditions although temperatures and nitrates were similar to autumn and spring, we hypothesize that irradiance was the most likely determinant of PE:cell.

Large increases in PE:cell with depth in autumn and spring, apparently due to photoadaptation, may explain, at least in part, the observed increase in $\alpha: c h l(\alpha$ is the rate of $\mathrm{C}$ incorporation per unit incident light; in $\mathrm{mg} \mathrm{C} \mathrm{m}{ }^{-3} \mathrm{~h}^{-1} \mathrm{PAR}^{-1}$ ) and $\alpha$ :cell with depth for populations of Synechococcus in the Northwest Atlantic Ocean (Prézelin et al. 1986). This increase in PE:cell at low light intensities was observed also for cultures of WH7803 (Kana \& Glibert 1987a) with a concomitant increase in the size of the photosynthetic unit (PSU). Indeed, such an increase in the ratio of PE:cell with depth has been observed in field populations of Synechococcus spp, in the North Atlantic (Glover et al. 1988) using a non-extractive method of PE estimation.

Several interesting conclusions can be drawn from this study: (1) Coastal Synechococcus seem to belong to the type of clones with high PUB:PEB ratios, similar to the cells found in open ocean waters. (2) These cells were capable of rapid growth but maintained a relatively low abundance from autumn to spring suggesting a rapid turnover rate, probably due to high grazing rates on Synechococcus. (3) The distribution of cells for these coastal waters, characterized by highest abundances and growth rates close to the sea surface, would allow for reasonable estimation of Synechococcus cell numbers using airborne or satellite sensors. (4) The amount of PE in the water column was mostly dependent on Synechococcus abundance near the surface. In deeper waters, PE:cell increased with depth while absolute number of cells and pigment concentrations decreased. (5) Values of PE:cell were maximal for cells below the $1 \%$ isolume for PAR. PE:cell was positively correlated to nitrate concentration and inversely correlated to light and temperature. All physical parameters were correlated with depth for the total data set. However, since PE:cell remained low in winter when water clarity was maximal, while nutrients and temperature were similar to spring and autumn values, we conclude that light intensity was the principal factor determining PE:cell at this coastal station.

Acknowledgements. This work was sponsored by NASA grants NAS7-934 to Biospherical Instruments, Inc. and NAGW-1070 to O.H.-H and B.G.M. We wish to thank C. R. Booth for the use of the MER spectroradiometer unit; $R$. McConnaughey for assistance in skiff deployment and mooring maintenance; Drs F. Azam and G. Somero for the use of the fluorescence microscope and spectrofluorometer, respectively; Dr B. Jones for access to the autoanalyzer at the University of Southern California; J. Gaylord for the cell counts; E. Olson for nutrient analysis and technical assistance throughout this study; and E. Brody for data analysis and graphics.

\section{LITERATURE CITED}

Alberte, R., S., Wood, A. M., Kursar, T A., Guillard, R. R. L. (1984). Novel phycoerythrins in marine Synechococcus spp. Characterization and evolution and ecological implications. Plant Physiol. 75: 732-739

Barlow, R. G., Alberte, R. S. (1985). Photosynthetic characteristics of phycoerythrin-containing marine Synechococ- 
cus spp. I. Responses to growth photon flux density. Mar. Biol. 86: 63-74

Booth. R. C., Mitchell, B. G., Holm-Hansen, O. (1987). Development of moored oceanographic spectroradiometer. Final Report. Biospherical Instruments Inc., San Diego, $87-1$, p. 69

Campbell, L., Iturriaga, R. (1988). Identification of Synechococcus spp. in the Sargasso Sea by inmunofluorescence and fluorescence spectroscopy performed on individual cells. Limnol. Oceanogr. 33: 1196-1201

Carpenter, E. J., Campbell, L. (1988). Diel patterns of cell division and growth rates of Synechococcus spp. in Long Island Sound. Mar Ecol. Prog. Ser. 47: 179-183

El Hag, A. G. D., Fogg, G. E. (1986). The distribution of coccoid blue-green algae (Cyanobacteria) in the Menai Straits and the Irish Sea. Br. phycol. J. 21. 45-54

Gantt, E. (1979). Phycobiliproteins of Cryptophyceae. In: Levandowsky, M. Hutner, S. H. (eds.) Biochemistry and physiology of Protozoa, 2nd edn., Vol. 1. Academic Press, New York, p. 121-137

Gieskes, W W. C., Kraay, G. W. (1983). Dominance of Cryptophyceae during phytoplankton spring bloom in the central North Sea detected by HPLC analysis of pigments. Mar. Biol. 75: 179-185

Glibert, P. M., Kana, T. M., Olson, R. J., Kirchman, D. L., Alberte, R. S. (1986). Clonal comparisons of growth and photosynthetic response to nitrogen availability in marine Synechococcus spp. J. exp. mar Biol. Ecol 101: 198-208

Glover, H. E. (1985). The physiology and ecology of the marine cyanobacterial genus Synechococcus. In: Jannasch, H. W., Williams, P. J. Le B. (eds.) Advances in aquatic microbiology, Vol. 3. Academic Press, London, p. 49-107

Glover, H. E., Prézelin, B. B., Campbell, L., Wyman, M. (1988). Pico- and ultraplankton Sargasso Sea communities: variability and comparative distributions of Synechococcus spp. and algae. Mar. Ecol. Prog. Ser. 49: 127-139

Gordon, H. R., Clar, D. K., Brown, O. B., Evans, R. H., Broenkow, W. W. (1983). Phytoplankton pigment concentrations in the Middle Atlantic Bight: comparison of ship determinations and CZCS estimates. Appl. Opt. 22: 20-36

Gordon, H. R., McCluney, W. R. (1975). Estimation of the depth of sunlight penetration in the sea for remote sensing. A.ppl. Opt. 14: 413-416

Haxo, F. T., Lewin, R. A., Lee, K. W., Li, M.-R. (1987). Fine structure and pigments of Oscillatoria (Trichodesmium) aff. thiebautii (Cyanophyta) in culture. Phycologia 26: $443-456$

Hobbie, J. E., Daley, J., Jasper, S. (1977). Use of nuclepore filters for counting bacteria by fluorescence microscopy. App. Environ. Microbiol. 33: 1225-1228

Hoge, F. E., Swift, R. N. (1986). Active-passive correlation spectroscopy: a new technique for identifying ocean color algorithm spectral regions. App. Opt. 25: 2571-2583

Holm-Hansen, O., Riemann, B. (1978). Chlorophyll a determination: improvements in methodology. Oikos 30: 438-447

Iturriaga, R., Mitchell, B. G. (1986). Chroococcoid cyanobacteria: a significant component in the food web dynamics of the ocean. Mar. Ecol. Prog. Ser 28: 291-297

Kana, T M., Glibert, P. M. (1987a). Effect of irradiances up to $2000 \mu \mathrm{E} \mathrm{m}^{-2} \mathrm{~s}^{-1}$ on marine Synechococcus WH 7803 - I. Growth, pigmentation, and cell composition. Deep Sea Res. 34 (4A): $479-495$
Kana, T M. Glibert, P. M. (1987b). Effect of irradiances up to $2000 \mu \mathrm{E} \mathrm{m}^{-2} \mathrm{~s}^{-1}$ on marine Synechococcus WH7803 - II. Photosynthetic responses and mechanisms. Deep Sea Res. 34 (4A) $497-516$

Kilpatrick, K. A. (1985). The development of a method to measure marine cyanobacterial phycoerythrin extracted in solvents. M. S. thesis, Texas A\&M University

Kirchman, D. L., Alberte, R. S. (1985). Phycoerythrin as a nitrogen storage pool in marine Synechococcus. EOS (Trans. Am. Geophys. Un.) 66 (51): 1302

Krempin, D. W., Sullivan, C. W. (1981). The seasonal abundance, vertical distribution, and relative microbial biomass of chroococcoid cyanobacteria at a station in southern California coastal waters. Can. J. Microbiol. 27: 1341-1344

Kursar, T A., Alberte, R. S. (1983). Photosynthetic unit organization in a red alga. Plant Physiol. 72: 409-414

Landry, M. R., Haas, L. W. Fagerness, V L. (1984). Dynamics of microbial plankton communities: experiments in Kaneohe Bay, Hawaii. Mar. Ecol. Prog. Ser. 16: 127-133

MacColl, R., Berms, D. S., Gibbons, O. (1976). Characterization of cryptomonad phycoerythrin and phycocyanin. Arch. Biochem. Biophys. 177: 265-275

Mitchell, B. G., Kiefer, D. A. (1988). Chlorophyll a specific absorption and fluorescence excitation spectra for lightlimited phytoplankton. Deep Sea Res. 35: 639-663

Ong, L., Glazer, A. N., Waterbury, J. B. (1984). An unusual phycoerythrin from a marine cyanobacterium. Science 224: 80-83

Prézelin, B. B., Putt, M., Glover, H. E. (1986). Diurnal patterns in photosynthetic capacity and depth-dependent photosynthesis-irradiance relationships in Synechococcus spp. and larger phytoplankton in three water masses in the Northwest Atlantic Ocean. Mar. Biol. 91: 205-217

Putt, M., Prézelin, B. B. (1985). Observations of diel patterns of photosynthesis in cyanobacteria and nanoplankton in the Santa Barbara Channel during 'El Niño' J. Plankton Res. 7: 779-790

Steemann Nielsen, E. (1952). The use of radio-active carbon for measuring organic production in the sea. J. Cons, int. Explor. Mer 18: 117-140

Stewart, D. E., Farmer, F. H. (1984). Extraction, identification, and quantitation of phycobiliprotein pigments from phototrophic plankton. Limnol. Oceanogr 29: 392-397

Strickland, J. D. H., Parsons, T. R. (1972). A practical handbook of seawater analysis. Bull. Fish. Res. Bd Can. 167

Waterbury, J. B., Watson, S. W., Guillard, R. R. L., Brand, L. E. (1979). Widespread occurrence of a unicellular, marine, planktonic, cyanobacterium. Nature, Lond. 277: 293-294

Waterbury, J. B., Watson, S. W., Valois, F. W., Franks, D. G (1986). Biological and ecological characterization of the marine unicellular Cyanobacterium Synechococcus. In: Platt, T. Li, W. K. W (eds.) Photosynthetuc picoplankton. Can. Bull. Fish. Aquat. Sci. 214: 71-120

Wyman, M., Gregory, R. P. F., Carr, N. G. (1985). Novel role for phycoerythrin in a marine cyanobacterium, Synechococcus strain DC2. Science 230: 818-820

Yamanaka, G. C., Glazer, A. N. (1980). Dynamic aspects of phycobilisome structure: phycobilisome turnover during nitrogen starvation in Synechococcus spp. Arch. Microbiol. 124: $39-47$

Zar, J. H. (1984). Biostatical analysis, 2nd edn. Prentice-Hall, Inc., Englewood Cliffs

Manuscript first received: September 28, 1989

Revised version accepted: February 1, 1990 